\title{
The Economic Impact of \\ Los Alamos National Laboratory \\ on North-Central New Mexico and the \\ State of New Mexico Fiscal Year 1998
}

by

Robert R. Lansford, Professor

Department of Agricultural Economics and Agricultural Business

New Mexico Agricultural Experiment Station

New Mexico State University

Las Cruces, New Mexico

and

Larry D. Adcock, Economist

Lucille M. Gentry, Program Analyst

Institutional Management Branch

Laboratory Programs Division

Office of Technology and Site Programs

Albuquerque Operations Office

U.S. Department of Energy

Albuquerque, New Mexico

and

Shaul Ben-David

Professor, Emeritus

Department of Economics

University of New Mexico

Albuquerque, New Mexico

and

John Temple

Consulting Economist

Albuquerque, New Mexico 


\section{DISCLAIMER}

This report was prepared as an account of work sponsored by an agency of the United States Government. Neither the United States Government nor any agency thereof, nor any of their employees, make any warranty, express or implied, or assumes any legal liability or responsibility for the accuracy, completeness, or usefulness of any information, apparatus, product, or process disclosed, or represents that its use would not infringe privately owned rights. Reference herein to any specific commercial product, process, or service by trade name, trademark, manufacturer, or otherwise does not necessarily constitute or imply its endorsement, recommendation, or favoring by the United States Government or any agency thereof. The views and opinions of authors expressed herein do not necessarily state or reflect those of the United States Government or any agency thereof. 


\section{DISCLAIMER}

Portions of this document may be illegible in electronic image products. Images are produced from the best available original document. 


\section{PREFACE}

The Albuquerque Operations Office (AL) of the U.S. Department of Energy (DOE) is charged with managing laboratories, production plants, and energy programs in several locations throughout the United States, including New Mexico. Due to the significance of DOE activities in New Mexico, selected economic impact studies have been completed annually since the early $1980 \mathrm{~s}$. The types of activities that DOE/AL oversees are, for the most part, an outgrowth of atomic research that started in New Mexico in the 1940s. In New Mexico, activity that was once confined to "The Hill" (Los Alamos National Laboratory), northwest of Santa $\mathrm{Fe}$, has become two national laboratories, a national waste repository, a national remedial action project, and several energy research and conservation programs.

The economic impact on New Mexico has grown over the years to a point where these activities provide tens of thousands of jobs and contribute billions of dollars to the state's economy. Therefore, it is appropriate that a report be provided periodically to the citizens of New Mexico describing the impact of DOE on the state. This report details activities for Federal Fiscal Year 1998.

\section{ACKNOWLEDGMENTS}

As is the case with studies of this type, many more people contribute to the effort than just the listed authors. The detailed information needed for the economic modeling and expenditure analysis could not have been obtained without the support of several individuals. Moreover, there are some who contribute but their contributions are not always acknowledged - - to those individuals, we apologize.

The employment data by economic sector used in the regional model was obtained from the New Mexico Department of Labor (NMDOL). Steve Pazand, Unit Supervisor, Actuarial Research, NMDOL made certain we obtained the detailed, but unpublished data needed for our research. Larry Blackwell, Chief, Economic Research and Analysis Bureau, NMDOL, also assisted the study team in obtaining the appropriate data. Importantly, this state government department has cooperated fully with our research efforts for several years and should be commended for their continuing efforts to participate in regional economic studies.

Luella Aragon, Staff Accountant, Albuquerque Financial Service Center, Department of Energy (DOE) Albuquerque Operations Office, contacted all the DOE agencies to obtain expenditure information for this study. We thank the LANL financial officials who provided budget and expenditure data in a timely fashion, specifically Allan Johnston, Tom Short, and Randy Hodges from LANL's Controller Office. Also, we thank Rita Spencer, Quality and Planning Office, who provided summarized achievements information. Last but not least, we also thank Irma Marshall, NMSU, for her assistance in typing the report. 


\section{TABLE OF CONTENTS}

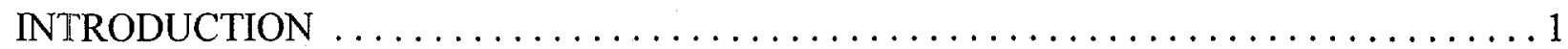

PROFILE OF LOS ALAMOS NATIONAL LABORATORY $\ldots \ldots \ldots \ldots \ldots \ldots \ldots \ldots$

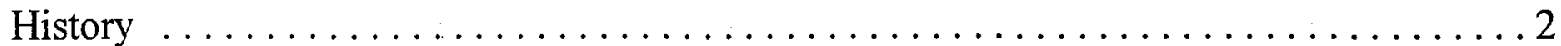

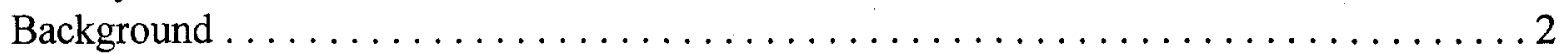

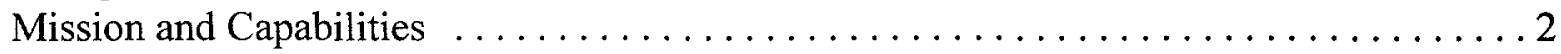

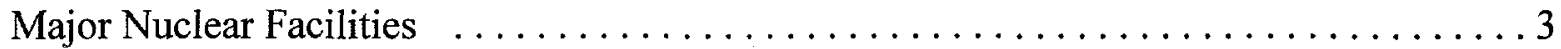

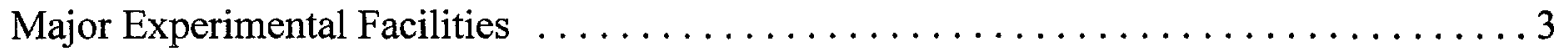

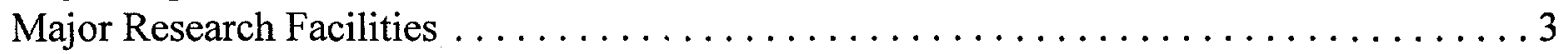

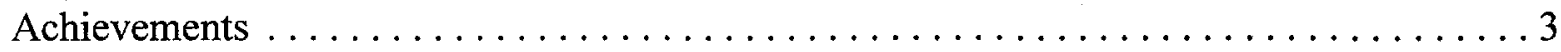

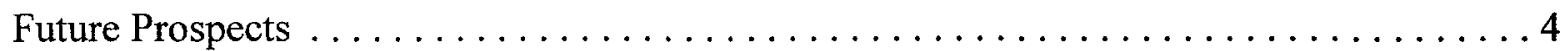

ECONOMIC IMPACTS OF LANL ON NORTH-CENTRAL NEW MEXICO, FY $1998 \ldots 4$

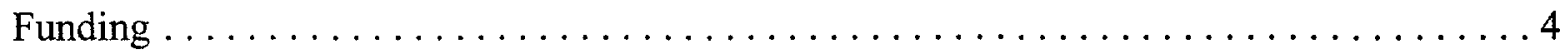

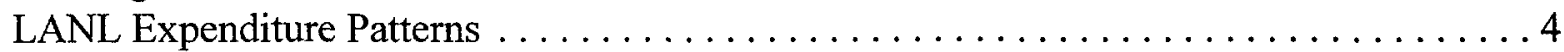

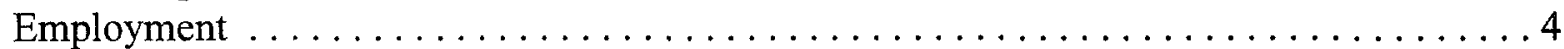

Measuring the LANL Economic Impact on North-Central New Mexico . . . . . . . . 4

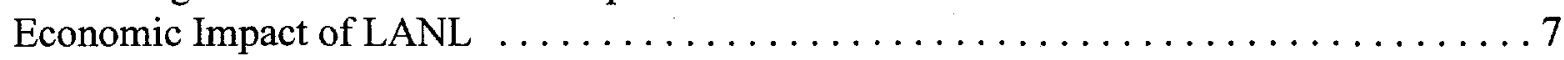

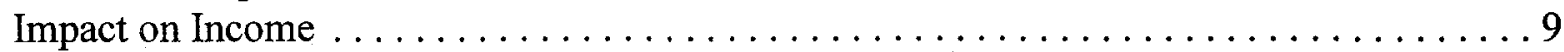

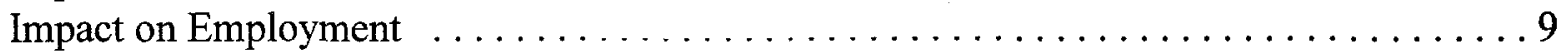

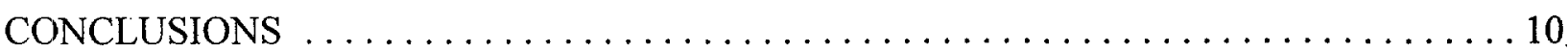

ECONOMIC IMPACTS OF LANL ON THE STATE OF NEW MEXICO, FY 1998 . . . . . . 10

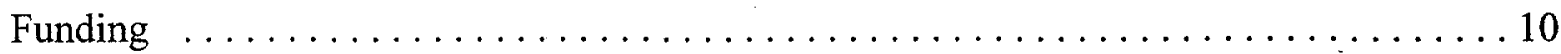

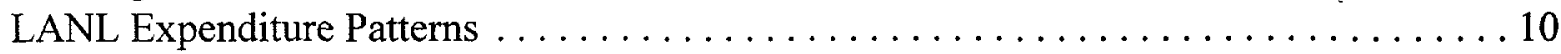

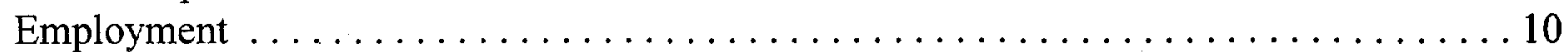

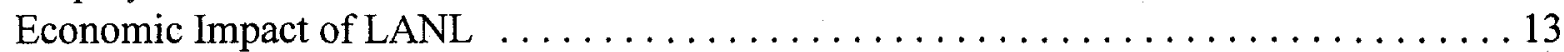

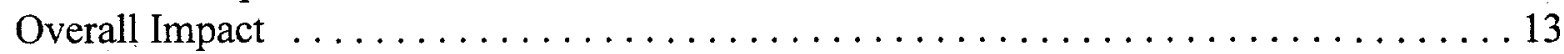

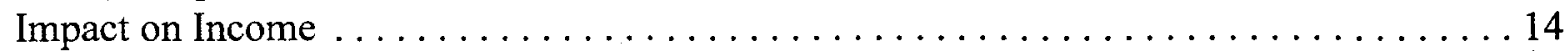

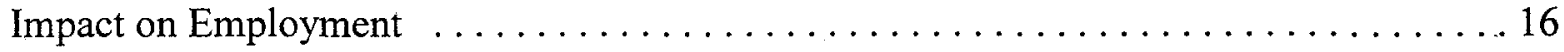

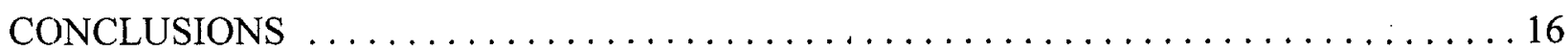

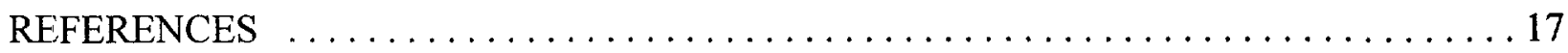

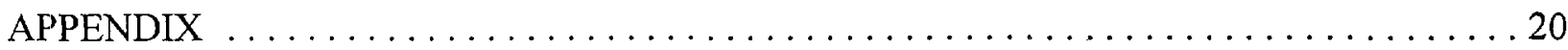




\section{LIST OF TABLES}

Table 1. LANL Expenditures (in dollars) in North-Central NM by Sector and Operating Budget, FY 1998. .............................

Table 2. LANL Expenditures in North-Central New Mexico by Major Sector, FY 1998.

Table 4. LANL Regional Influence on North-Central New Mexico's Economy, FY 1998

Table 5. LANL Expenditures (in dollars) in New Mexico by Sector and Operating Budget, Contractors, FY 1998.

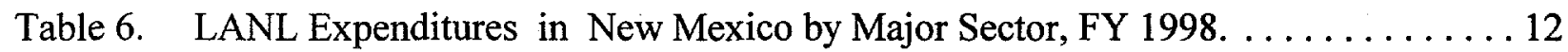

Table 7. LANL Funding, Instate Expenditures, and Employment in New Mexico, FY 1998

Table 8. LANL State Influence on New Mexico's Economy, FY 1998. 15

Table 9. LANL Central New Mexico I/O Model Direct Coefficients, FY 1998 22

Table 10. LANL Statewide I/O Model Direct Coefficients, FY $1998 \ldots$ 23

Table 11. Indirect Volume and Employment Impacts by Sector, LANL, North-Central New Mexico, FY 1998

Table 12. Indirect Volume and Employment Impacts by Sector, LANL, State Of New Mexico, FY 1998 25

\section{LIST OF FIGURES}

Figure 1. LANL Three County North-Central New Mexico Region. ...............

Figure 2. LANL Expenditures in North-Central New Mexico by Major Sector, FY 1998. . . 6

Figure 3. LANL Economic Impact on North-Central New Mexico, FY $1998 \ldots \ldots \ldots \ldots \ldots 7$

Figure 4. LANL Expenditures in New Mexico by Major Sector, FY $1998 . \ldots \ldots \ldots \ldots$

Figure 5. LANL Economic Impact on the State of New Mexico, FY $1998 \ldots \ldots \ldots \ldots . . .14$ 


\section{INTRODUCTION}

As a multidisciplinary, multiprogram laboratory, Los Alamos National Laboratory (LANL) is a key national resource for developing and integrating leading-edge science and technology to solve national and global security problems. The Laboratory's mission is to enhance global security by ensuring the safety and reliability of the U.S. nuclear weapons stockpile; reducing threats to U.S. security with a focus on weapons of mass destruction; cleaning up the legacy of the Cold War; and providing technical solutions to energy, environment, infrastructure, and health security problems. LANL promotes U.S. industrial competitiveness by working with U.S. companies in technology transfer and technology development partnerships. LANL is involved in partnerships and collaborations with other federal agencies, with industry (including New Mexico businesses), and with universities worldwide.

For several years, the U.S. Department of Energy (DOE) Albuquerque Operations Office (AL) and New Mexico State University (NMSU) have maintained an inter-industry, input-output ( $(\mathrm{O} / \mathrm{O})$ model that has the capability to assess the effect on an economy of developments initiated from outside the economy (exogenous changes on New Mexico)--federal LANL monies that flow into a region or state. This model will be used to assess economic, personal income, and employment impacts of LANL on North-Central New Mexico (a three-county region consisting of Los Alamos, Santa $\mathrm{Fe}$, and Rio Arriba Counties) and the state of New Mexico (Figure 1). Caution should be exercised when comparing economic impacts between fiscal years prior to this report. The $\mathrm{I} / \mathrm{O}$ model was rebased for FY 1998. The fringe benefits coefficients have been updated for the FY 1996 and FY 1997 economic impacts analysis. Prior to FY 1993 two different I/O base models were used to estimate the impacts. New technical information was released by the Bureau of Economic Analysis (BEA), U.S. Department of Commerce in 1991 and in 1994 and was incorporated in FY 1991, FY 1993, and FY 1994 $\mathrm{I} / \mathrm{O}$ models. Also in 1993, the state and local tax coefficients and expenditure patterns were updated from a 1986 study for the FY 1992 report.

Further details about the $\mathrm{I} / \mathrm{O}$ model can be found in "The Economic Impact of the Department of Energy on the State of New Mexico - FY 1998" report by Lansford, et al. (1999).

For this report, the reference period is FY 1998 (October 1, 1997, through September 30, 1998) and includes two major impact analysis: the impact of LANL activities on North-Central New

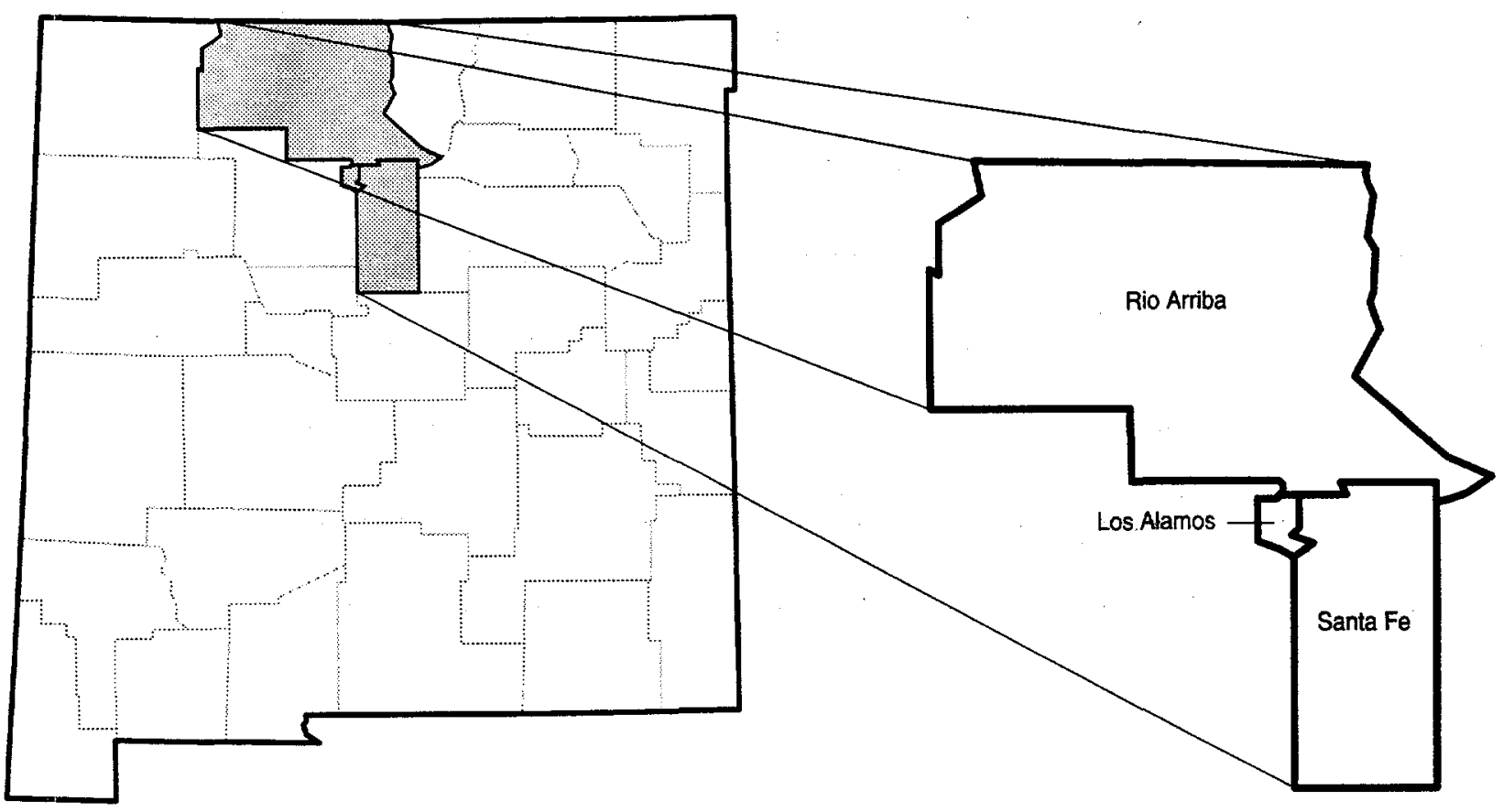

Figure 1. LANL Three County North-Central New Mexico Region. 
Mexico and the economic impacts of LANL on the state of New Mexico. Total impact represents both direct and indirect respending by business, including induced effects (respending by households). The standard multipliers used in determining impacts result from the inter-industry, I/O models developed for the three-county region and the state of New Mexico.

\section{PROFILE OF LOS ALAMOS NATIONAL LABORATORY}

\section{History}

LANL was established in 1943 as the Wartime Project $Y$ of the Manhattan Engineering District with responsibility for developing the first nuclear weapon. During the cold-war era, Los Alamos became a multidiscipline, multiprogram Laboratory applying capabilities from its original weapons mission to national security and civilian security needs. In this post cold-war era, the Laboratory continues its scientific role in national security as a steward of the enduring stockpile. It applies scientific capabilities to the reduction of threats from weapons of mass destruction and to civilian security threats.

\section{Background}

The Laboratory is located in Los Alamos County, New Mexico. The county covers 110 square miles and had a 1997 population of 18,275 (Bureau of the Census, 1997). The Laboratory is operated by the University of California for the U.S. Department of Energy under contract W-7406-ENG-36, and is an affirmative action/equal opportunity employer.

During 1998, the Laboratory had approximately 8,931 University of California employees, by headcount, (including full-time, part-time, paid and unpaid affiliate, visiting, and casual status) and an additional 1,800 contract employees, vendors, members of the protective guard force, and contractor personnel.

The 1998 operating budget was $\$ 1.3$ billion. Principal activities are as follows: Defense Programs 53 percent, Nonproliferation and National Security 9 percent, Materials Disposition 12 percent, Environmental Restoration and Waste Management 12 percent, Energy Research 5 percent, Nuclear Energy 1 percent, Energy Efficiency and
Renewable Energy 1 percent, other DOE 2 percent, and Work for Others 15 percent.

Administrative, research, and maintenance facilities occupy more than 5.1 million occupiable square feet of the available 8 million gross square feet of building space, of which 2.3 percent is leased in the community. The 34 technical areas are scattered over about 43 square miles $(27,800$ acres). These technical areas occupy about 39 percent of the total county area.

Because of topographical, environmental, operational, and buffering constraints, only about 30 percent of the 27,800 acres of DOE land is developable. The facilities, including buildings, infrastructure, and capital equipment, have an estimated replace-ment cost of $\$ 4.2$ billion.

LANL is involved in partnerships and collaborations with other federal agencies, with industry, and with over 230 universities worldwide. In addition, the Laboratory is committed to helping diversify the regional economy and enhance educational opportunities.

The Laboratory, DOE, and the Los Alamos Economic Development Corporation (LAEDC), with support from the county of Los Alamos, is pursuing the development of a research and development park. The park is proposed to be developed on about 44 acres of land directly north of the Laboratory's main area. This land and park are intended to provide a physical location for private industry to develop facilities that will allow and foster scientific and technological exchange between private industry and the Laboratory.

\section{Mission and Capabilities}

The Laboratory's core mission is to enhance global security by ensuring safety and confidence in the U.S. nuclear weapons stockpile, by developing technical solutions to reduce the threat of weapons of mass destruction, and by improving the environmental and nuclear materials legacy of the cold war.

In addition, the Laboratory applies its scientific and engineering capabilities to assist the nation in addressing energy, environment, infrastructure, and biological security problems. For example, the high-performance computing capability and related competencies address national problems as 
wide-ranging as epidemics, global warming, traffic patterns, and forest fires.

The Laboratory's strength derives from its ability to solve extremely complex problems that require the integration of an array of disciplines and capabilities with highly specialized facilities and unique operations expertise.

LANL supports DOE complex wide initiatives in all four of DOE's business areas: National Security, Science and Technology, Energy Resources, and Environmental Quality. In addition, it performs work for other federal agencies, and works with U.S. industry that is synergistic with its core mission.

\section{Major Nuclear Facilities}

Plutonium Facility-the Nation's only full-service operating plutonium facility.

Weapons Engineering Tritium Facility-state-of-theart tritium research and development facility.

Critical Experiments Facility-national resource for critical-assembly training and nuclear data measurements.

Chemistry and Metallurgy Research Facilityfacilities for plutonium metallurgy, advanced chemical diagnostics, and nuclear and radiochemistry.

\section{Major Experimental Facilities}

Neutron Science Center-national user facility includes one of the world's most powerful proton linear accelerators and the proton storage ring.

Materials Science Laboratory-specialized laboratory that provides experiments in hightemperature superconductivity, materials modification, and materials analysis.

Dual-Axis Radiographic Hydrotest Facility- premier three-dimensional hydrotest center; expected to begin operations in 1999 .

National High Magnetic Field Laboratory-unique facility that will produce 100-tesla magnetic fields for periods lasting up to 10 milliseconds (1000 times longer than anywhere else in the world).

\section{Major Research Facilities}

Advanced Computing Laboratory-new facility to provide resources for advances in high-performance computing; Strategic Computing Complex-TeraOp computing and simulation (construction begins in 1999).

Health Research Laboratory-contains the Center for Human Genome Stidies, biological research, molecular biology, biochemistry, and genetics.

\section{Achievements}

- Developed first nuclear weapons (1945);

- Demonstrated the ignition of thermonuclear fuel (1951);

- Tested first thermonuclear weapon (1952);

- Designed the majority of weapons in the nuclear stockpile and the first flash $\mathrm{x}$-ray radiographic facility (1963) and holds responsibility for stewardship of the weapons;

- Developed VELA Satellite for verification of atmospheric test-ban treaty (1963); and

- Major contributions to the development of large scale computers and computation and to nuclear reactor design:

MANIAC II computer (1956), IBM's STRETCH (1961), Cray computer (1976), Thinking Machines Corp. CM-2 (198990), Monte-Carlo method (1947), and the $S_{n}$ discrete ordinates method (1953) for solving radiation transport computations, the particle-in-cell method of numerical fluid dynamics (1957), computer codes to analyze reactor safety (1979);

Blue Mountain standard speed test ran at 1.6 teraOps. (1998);

Achievement of criticality: uranium solution-fueled reactor (1944);

First plutonium-fueled reactor (1946); "Lady Godiva" critical assembly (1953); KIWI reactor (1960); and Phoebus reactor (1965); for nuclear-powered rocket program, and operation of UHTREX reactor (1969).

- Major contributions in fundamental science including:

Detection of neutrino $(1956,1995$ Nobel Prize in physics), first demonstration of thermonuclear plasma in laboratory fusion studies (1958), use of high intensity LAMPF proton accelerator for 
nuclear studies (1972), discovery of heavyfermion superconductor (1982).

- Recently:

Detection of single fluorescent molecules, first flow cytometer for sorting single biological cells, discovery of the human telomere, complete sequencing of chromosome 16, measurement of neutrino mass, computer modeling of global ocean temperatures. Detection of ionic pulsedpairs of radio impulses by an instrument aboard a satellite, new milestones in high temperature superconductivity and materials processing, Advanced Recovery and Integrated Extraction System (ARIES) for Plutonium, characterization of the earth's changing magnetic field and the spin-rate of the earth's core, detection of lunar ice, and detection of evidence for a super-massive black hole.

\section{Future Prospects}

Los Alamos will continue its roles in science-based stockpile stewardship and in nonproliferation and counter-proliferation. The Laboratory has been designated as the preferred location to manufacture nuclear weapon pits on a small scale. High performance computing, with its associated capabilities, is expected to address additional complex civilian security problems.

\section{ECONOMIC IMPACTS OF LANL ON NORTH-CENTRAL NEW MEXICO, FY 1998}

\section{Funding}

Throughout this chapter, funding to or expenditures by major on-site contractors or LANL will be referred to as "activities by LANL" for simplicity. The total LANL funding (operating and capital budget) in North-Central New Mexico in FY 1998 was over $\$ 1.3$ billion (Table 1). LANL regional (Los Alamos, Santa Fe, and Rio Arriba Counties) expenditures were $\$ 773$ million in FY 1998 for salaries and wages, trade and services, capital equipment, and construction. University of California operating budget accounted for about 91 percent of the total North-Central New Mexico budget; Johnson Controls funding accounted for 7 percent; and Protection Technology accounted for about 2 percent.

\section{LANL Expenditure Patterns}

Total LANL regional expenditures (the initial respending of the total operating and capital budget) amounted to about $\$ 773$ million or about 58 percent of the total budget in FY 1998 (Table 1). The eight economic sectors accounting for the majority of LANL regional expenditures for FY 1998 were: households (\$576 million), engineering services ( $\$ 42$ million), retail trade (\$41 million), data processing and computer services ( $\$ 23$ million), wholesale trade ( $\$ 23$ million), other business services ( $\$ 15$ million), management and consulting services $(\$ 12$ million), and construction ( $\$ 10$ million). These sectors combined accounted for about 96 percent of total LANL regional expenditures (Table 1).

LANL expenditures by major sectors in North-Central New Mexico for FY 1998 were: personnel (including benefits) (\$576 million), services ( $\$ 100$ million), trade ( $\$ 63$ million), construction ( $\$ 10$ million), government ( $\$ 9$ million) manufacturing ( $\$ 8$ million), and other sectors ( $\$ 6$ million) (Table 2). By far the largest LANL expenditure in North-Central New Mexico was labor, 75 percent of the total regional expenditures. In FY 1998, 13 percent of the LANL expenditures went for services, 8 percent for trade, and one percent each for other sectors, government, construction and manufacturing (Figure 2).

\section{Employment}

LANL is managed and operated by the University of California with approximately 7,923 employees in the three-county region in FY 1998 (Table 3). Johnson Controls had 1,381 full-time employees in FY 1998 and Protection Technology had 453 employees. The total number of jobs (all types of personnel) regionwide directly associated with LANL averaged 9,757 for FY 1998. Subcontractors averaged 1,834 employees.

\section{Measuring the LANL Economic Impact on North-Central New Mexico}

The analysis of the LANL's economic impact on North-Central New Mexico employed an economic model that incorporates buying and selling linkages among regional industries. This 
Table 1. LANL Expenditures (in dollars) in North-Central NM by Sector and Operating Budget, FY 1998.

\begin{tabular}{|c|c|c|c|c|}
\hline Sector & $\begin{array}{l}\text { University of } \\
\text { California (a) }\end{array}$ & $\begin{array}{c}\text { Johnson } \\
\text { Controls, Inc. }\end{array}$ & $\begin{array}{c}\text { Protection } \\
\text { Technology Los } \\
\text { Alamos (b) }\end{array}$ & Total \\
\hline 1. Livestock \& Livestock Products & & & & 0 \\
\hline 2. Other Agricultural Products & & & & 0 \\
\hline 3. Forestry \& Fishery Products & & & & 0 \\
\hline 4. Agriculture, Forestry \& Fishery Services & 6,843 & & & 6,843 \\
\hline 5. Mining, Crude Petroleum \& Natural Gas & 11,909 & & & 11,909 \\
\hline 6. Construction & $10,234,104$ & & & $10,234,104$ \\
\hline 7. Ordnance \& Chemical Manufacturing & 274,075 & & & 274,075 \\
\hline 8. Food \& Kindred Products Manufacturing & & & & 0 \\
\hline 9. Textiles Products \& Apparel Manufacturing & 31,937 & & & 31,937 \\
\hline 10. Lumber \& Wood Products Manufacturing & 21,005 & & & 21,005 \\
\hline 11. Paper \& Publishing Manufacturing & 19,614 & & & 19,614 \\
\hline 12. Petroleum Refining \& Products Manufacturing & & & & 0 \\
\hline 13. Glass, Stone \& Clay Products Manufacturing & 35,187 & & & 35,187 \\
\hline 14. Primary \& Fabricated Metals Manufacturing & $3,347,190$ & & & $3,347,190$ \\
\hline 15. Computer, Office \& Service Equipment Manufacturing & $1,833,054$ & & & $1,833,054$ \\
\hline 16. Electrical Equipment Manufacturing & $2,276,724$ & & & $2,276,724$ \\
\hline 17. Scientific Instruments Manufacturing & & & & 0 \\
\hline 18. All Other Manufacturing & & & & 0 \\
\hline 19. Motor Freight Transportation \& Warehousing & 815 & & & 815 \\
\hline 20. All Other Transportation & 23,923 & & & 23,923 \\
\hline 21. Communication & 40,104 & 810,692 & & 850,796 \\
\hline 22. Electric \& Gas Utilities & 17,000 & $2,802,953$ & & $2,819,953$ \\
\hline 23. Water \& Other Utilities & & 19,759 & & 19,759 \\
\hline 24. Wholesale Trade & $22,552,838$ & & & $22,552,838$ \\
\hline 25. Retail Trade & $40,927,388$ & & & $40,927,388$ \\
\hline 26. Finance, Insurance \& Real Estate & $1,374,736$ & 439,951 & & $1,814,687$ \\
\hline 27. Hotel Restaurant \& Other Personal Services & 734,732 & 80,545 & & 815,277 \\
\hline 28. Data Processing \& Computer Services & $22,973,477$ & 239,318 & & $23,212,795$ \\
\hline 29. Management \& Consulting Services & $12,768,603$ & & & $12,168,603$ \\
\hline 30. Engineering, Architecture \& Surveying Services & $42,265,195$ & & & $42,265,195$ \\
\hline 31. Other Business Services & $14,631,908$ & & & $14,631,908$ \\
\hline 32. Automobile \& Other Repair Services & 667,927 & $2,248,112$ & & $2,916,039$ \\
\hline 33. Amusement, Recreation \& Video Services & 64,500 & & & 64,500 \\
\hline 34. Health, Education \& Social Services & $2,513,743$ & $1,836,142$ & & $4,349,885$ \\
\hline 35. Government Services & $8,143,709$ & & & $8,143,709$ \\
\hline 36. Local Government & & 336,003 & & 336,003 \\
\hline 37. State Government & & 464,004 & & 464,004 \\
\hline 38. Los Alamos National Laboratory (c) & & & & 0 \\
\hline 39. Households & $490,566,508$ & $63,467,504$ & $22,042,451.00$ & $576,076,463$ \\
\hline Total Regional Expenditures & $677,758,748$ & $72,744,983$ & $22,042,451$ & $772,546,182$ \\
\hline Total Operating and Capital Budget & $1,206,486,093$ & $90,353,696$ & $30,609,219$ & $1,327,449,008$ \\
\hline Number of Employees & 7,923 & 1,381 & 453 & 9,757 \\
\hline
\end{tabular}

a. The LANL Total Operating and Capital Budget has been adjusted to account for contracts to Johnson Controls, Inc.,

Protection Technology - Los Alamos and other NM DOE management \& operating contracts.

b. Expenditures by PT-LA with the exception salaries and wages are included in LANL's Total Operating and Capital Budget.

c. Any transfer of money for services or products between specified activities is counted only in the activity of the last receiving agency. 
Table 2. LANL Expenditures in North-Central New Mexico by Major Sector, FY 1998.

\begin{tabular}{|c|c|c|c|}
\hline & Sector & $\begin{array}{l}\text { thousands of } \\
\text { dollars }\end{array}$ & Percent \\
\hline \multirow[t]{4}{*}{ I. } & Personnel & & \\
\hline & A. Salaries \& Wages & 488,265 & 63.2 \\
\hline & B. Benefits & 87,811 & 11.4 \\
\hline & Total & 576,076 & 74.6 \\
\hline 11 & Construction & 10,234 & 1.3 \\
\hline$\|$ & Manufacturing & 7,839 & 1.0 \\
\hline IV & Trade & 63,480 & 8.2 \\
\hline v. & Services & 100,424 & 13.0 \\
\hline \multirow[t]{5}{*}{11} & Government & & \\
\hline & A. Local Government & 336 & 0.0 \\
\hline & B. State Government & 464 & 0.1 \\
\hline & C. Government Services & 8,144 & 1.1 \\
\hline & Total & 8,944 & 1.2 \\
\hline
\end{tabular}

VII. Other Sectors
A. Agriculture
B. Mining

$\begin{array}{rr}7 & 0.0 \\ 12 & 0.0\end{array}$
C. T.C.U.(a)
3,715
0.5
D. F.I.R.E.(b)
1,815
0.2
Total
5,549
0.7

\section{TOTAL EXPENDITURES}

$772,546 \quad 100.0$

*Totals may not add due to rounding

a. Transportation, Communications, and Utilities

b. Finance, Insurance and Real Estate

analysis measures the impact generated by LANL and contractors expending money in the three North-Central counties (Los Alamos, Sante Fe, and Rio Arriba) of New Mexico.

Several useful products of the $1 / O$ modeling technique are multipliers. Three multipliers (the first related to general economic activity, the first related to general economic activity, the second to income, and the third to employment) provide information needed to estimate LANL's impact. The activity multiplier identifies the extent to which an activity, such as LANL, relies directly and indirectly on the regional economy to provide it with the materials, services, and labor that it

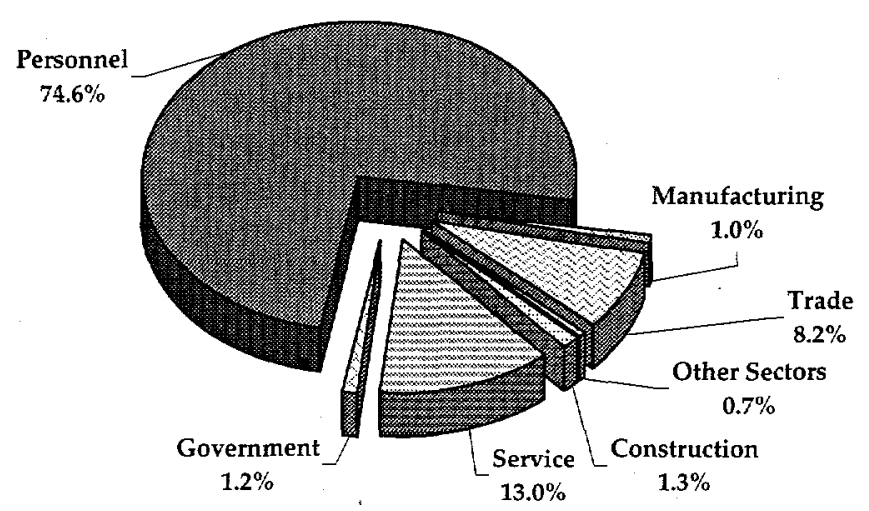

Figure 2. LANL Expenditures in NorthCentral New Mexico by Major Sector, FY 1998.

Table 3. LANL Funding, In-Region Expenditures, and Employment in New Mexico, FY 1998.

\begin{tabular}{lccc}
\multicolumn{1}{c}{ Entity } & $\begin{array}{c}\text { New Mexico } \\
\text { Funding }\end{array}$ & $\begin{array}{c}\text { Regional } \\
\text { Expenditures }\end{array}$ & $\begin{array}{c}\text { Regional } \\
\text { Employment }\end{array}$ \\
\hline $\begin{array}{l}\text { University of } \\
\text { California }\end{array}$ & $1,206.5$ & 677.8 & 7,923 \\
& 90.4 & 72.7 & 1,381 \\
$\begin{array}{l}\text { Johnson } \\
\text { Controls }\end{array}$ & 30.6 & 22.0 & 453 \\
PT-LA & $1,327.4$ & 772.5 & 9,757 \\
\hline
\end{tabular}

requires to conduct its activities, and the extent to which respending by businesses and industries occurs in the region. Income and employment 


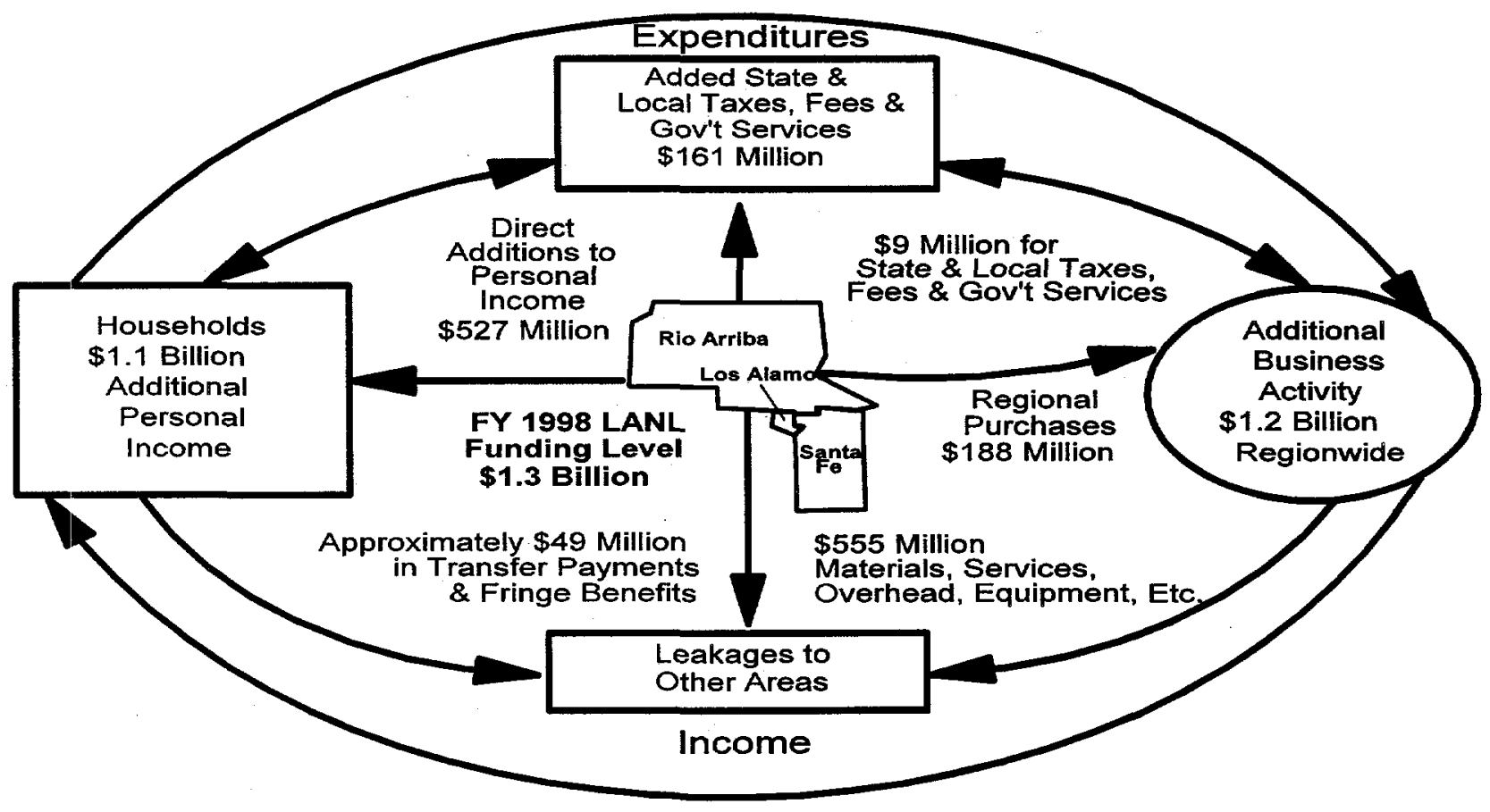

Total Regional Economic Impact - $\$ 3.8$ Billion

Figure 3. LANL Economic Impact on North-Central New Mexico, FY 1998.

multipliers make possible the identification of not only the direct impacts of an activity on income and jobs, but also the indirect (business) and induced (households) effects.

\section{Economic Impact of LANL}

The flow diagram (Figure 3 ) charts the movement of monies spent by LANL. Expenditures for salaries and purchases go to households, regional businesses, and other regions (outside the threecounty region of New Mexico). This injection of money affects economic activity directly: The effect equals the amount funded for LANL efforts in North-Central New Mexico ( $\$ 1.3$ billion).

Households and businesses affected by LANL respend much of the money they receive in the three-county region, thus creating indirect (business) and induced (household) effects. In turn, businesses buy from other local firms and pay salaries to their employees, starting another round of spending. Every movement of money around the circle causes additional indirect (and induced) effects. However, some funds leak outside the region when purchases are made elsewhere and are not available for further local spending. Thus, indirect effects become smaller and smaller as continued respending occurs.

The initial spending by LANL generates substantial first-round impacts on households (net) and businesses ( $\$ 527$ and $\$ 188$ million, respectively for FY 1998) in the three-county North-Central region (Figure 3 ). This initial spending will provide government with $\$ 9$ million in new revenues (mainly state and local government taxes, fees, and services). However, a large portion of the initial spending ( $\$ 555$ million) and transfer payments, including fringe benefits costs to labor ( $\$ 49$ million), flow out of state through leakages.

Respending by regional businesses and purchases by households and state and local government eventually brings the total private business impact to about $\$ 1.2$ billion. Also, respending activity will continue to add to personal income and government revenues so that total personal income will increase to $\$ 1.1$ billion, and state and local government tax revenues and government fees will expend $\$ 161$ million as a result of direct, indirect, and induced effects. 
Table 4. LANL Regional Influence on North-Central New Mexico's Economy, FY 1998.

\begin{tabular}{|c|c|c|c|}
\hline Economic Measure & LANL & Total Region & $\begin{array}{l}\text { LANL as \% } \\
\text { of Region }\end{array}$ \\
\hline & \multicolumn{2}{|c|}{-billions of dollars- } & \\
\hline \multicolumn{4}{|l|}{ Economic Activity } \\
\hline Direct Expenditures & 1.33 & & \\
\hline Indirect and Induced (a) & $\underline{2.50}$ & & \\
\hline Total Economic Activity & 3.83 & 12.9 & 29.7 \\
\hline Economic Activity Multiplier & 2.88 & & \\
\hline \multicolumn{4}{|l|}{ Personal Income } \\
\hline Gross Labor Costs & 0.57 & & \\
\hline Net Wage and Salaries & 0.53 & & \\
\hline Indirect and Induced (a) & $\underline{0.58}$ & & \\
\hline Total Personal Income & 1.11 & $4.2^{(\mathrm{a})}$ & 26.4 \\
\hline \multirow[t]{2}{*}{ Personal Income Multiplier } & 2.10 & & \\
\hline & \multicolumn{2}{|c|}{ - - number of employees - - } & \\
\hline \multicolumn{4}{|l|}{ Employment } \\
\hline Direct & 9,757 & & \\
\hline Indirect and Induced (a) & $\underline{17.931}$ & & \\
\hline Total Employment & 27,688 & $93,669^{(b)}$ & 29.6 \\
\hline Employment Multiplier & 2.84 & & \\
\hline
\end{tabular}

a. BEA May 1999

b. New Mexico Department of Labor, Table C, March 1999.

\section{Overall Impact}

Using LANL's funding for its total operating and capital budget of $\$ 1.3$ billion, econometric modeling techniques were used to calculate the effects of this funding. As Table 4 indicates, the total increase in economic activity in New Mexico was $\$ 3.8$ billion from the initial infusion of $\$ 1.3$ billion. The economic activity multiplier measures the volume of activity generated among various sectors of a region as a result of a $\$ 1$ exogenous change in a sector. For example, the economic activity multiplier for LANL for FY 1998 was 2.88. This indicates that for every $\$ 1$ spent by LANL and its major on-site New Mexico contractors, another $\$ 1.88$ was generated in the region for a total impact of $\$ 2.88$ in FY 1998 .

No official figure exists for total economic activity in the three-county north-central region; however, for the purposes of this study total 
economic activity in the three-county region is estimated at $\$ 12.9$ billion for 1998 (Table 4).

Applying the regional economic activity multiplier of 2.88 to the $\$ 1.2$ billion directly added to the regional economy results in the $\$ 3.8$ billion estimated total impact in FY 1998. This total impact of $\$ 3.8$ billion generated by LANL is about 30 percent of the estimated $\$ 12.9$ billion total economic activity in the region. Table 4 gives the direct, indirect, induced, and total economic activity impact of LANL on the region.

Tabie 11 in the Appendix gives LANL indirect economic impacts on private and public sectors for FY 1998. The retail trade sector received the greater volume of indirect private and public economic impacts, about 20 percent of the total estimated indirect impacts. Other sectors with large indirect economic impacts include: finance, insurance and real estate (FIRE) (16 percent); hotel, restaurant, and other personal services ( 6 percent); state government ( 6 percent); health, education, and social services ( 5 percent); other business services ( 5 percent); electric and gas utilities ( 4 percent); and wholesale trade ( 4 percent).

\section{Impact on Income}

Personal income is money that goes to individuals that will be respent for purchases such as groceries, automobiles and gasoline, mortgage payments, medical, clothing and new shoes, taxes and savings. Most personal income consists of wages and salaries, although payments received as interest, rent, dividends, and Social Security benefits (payments to individuals) also count as personal income. Some of the fringe benefits and wages paid to employees are not counted in the current income stream (i.e., Social Security payments by employers and employees). In FY 1998 , labor payments of $\$ 576$ million resulted in an estimated $\$ 527$ million in net additional personal income to the region.

Income multipliers measure the indirect and induced effects from new income generated from payment to labor by LANL. The income multiplier was 2.10 for FY 1998 (Table 4). This multiplier indicates that for every $\$ 1$ of personal income from LANL for labor, another $\$ 1.10$ is generated through indirect and induced effects, for a total impact on personal income of $\$ 1.11$ billion.
Applying the income multiplier of 2.10 to the direct net personal income figure of $\$ 527$ million yields a total impact of $\$ 1.11$ billion for income in the region resulting from LANL activity.

In FY 1998, total personal income in North-Central New Mexico was estimated at just over $\$ 4.0$ billion (Table 4). LANL activities in the North-Central New Mexico region accounted for about 26 percent of total regional personal income in 1998.

\section{Impact on Employment}

Beside this dollars-and-cents impact, LANL affects regionwide employment. In addition to the average of 9,757 jobs created by LANL in FY 1998 , other jobs are supported by the resulting needs for goods and services, and respending by individuals and businesses. Firms filling those needs have their own employees and, in turn, spend money with other firms who must also hire people. In addition, each individual employee needs goods and services and helps support other jobs such as waitresses, mechanics, clerks, lawyers, and nurses.

The employment multipliers measure the number of indirect and induced jobs supported, on the average, by LANL. The regional employment multiplier for LANL was estimated to be 2.84 in FY 1998 (Table 4). This indicates that for every 100 jobs created by LANL, another 184 jobs were supported in the region during FY 1998. This translated into 27,688 jobs created or supported by LANL or about 30 percent of total employment in the region in FY 1998 (Table 4).

Table 11 in the Appendix gives the LANL indirect employment impact on private and public sectors for FY 1998. The more labor-intensive sectors received the greater indirect employment impact. The retail trade sector had the largest indirect impact of about 31 percent. Other sectors with a large indirect employment impact include: hotel, restaurant and other personal services (12 percent); FIRE (10 percent); health, education and social services ( 8 percent); state government ( 6 percent); wholesale trade ( 4 percent), and other business services ( 4 percent). 


\section{CONCLUSIONS}

In summary, LANL operations in North-Central New Mexico have a significant and positive influence on the economy of North-Central New Mexico. The total funding for LANL in North-Central New Mexico was $\$ 1.3$ billion in FY 1998 , yielding a total economic impact of about $\$ 3.8$ billion or about 30 percent of the total economic activity in the region. Total personal income impact was $\$ 1.11$ billion in FY 1998 or about 26 percent of personal income derived in the three counties. The employment multiplier was 2.84 for the region, meaning that the 9,757 average employment level of FY 1998 supported a total impact of 27,688 . In effect, nearly one of every three jobs in the region was created or supported by LANL. Approximately 80 percent of the jobs created indirectly by LANL in the region occurred in the trade, FIRE and services sectors.

\section{ECONOMIC IMPACTS OF LANL ON THE STATE OF NEW MEXICO, FY 1998}

\section{Funding}

Throughout this chapter, funding to or expenditures by major on-site contractors or LANL offices will be referred to as "activities by LANL" for simplicity. The statewide total funding (operating and capital budget) for LANL for FY 1998 was over $\$ 1.3$ billion (Table 5). LANL's New Mexico expenditures were just under $\$ 1.0$ billion ( $\$ 962$ million) in FY 1998 for salaries and wages, trade and services, capital equipment, and construction. The University of California budget accounted for 90 percent of the total New Mexico expenditures; Johnson Controls funding accounted for 7 percent; and Protection Technology accounted for about 2 percent. The largest contractor supporting LANL in the state of New Mexico was Johnson Controls.

\section{LANL Expenditure Patterns}

Total LANL instate expenditures (the initial respending of the total operating and capital budget) amounted to about 72 percent of the total budget in FY 1998 (Table 5). Johnson Controls' total instate expenditures in New Mexico were $\$ 90$ million. In total, LANL instate expenditures were nearly $\$ 1.0$ billion in FY 1998 for salaries and wages, trade and services, capital equipment, and construction (Table 5).

Out-of-state purchases and salaries for those living elsewhere amounted to $\$ 365$ million. In addition, approximately $\$ 53$ million for transfer payments and some fringe benefit costs for instate labor costs leaked directly out of state.

The nine economic sectors accounting for the majority of LANL instate expenditures for FY 1998 were: households ( $\$ 628$ million), retail trade ( $\$ 69$ million), wholesale trade ( $\$ 59$ million), engineering, architecture, and surveying ( $\$ 49$ million), data processing and computer services ( $\$ 34$ million), electric and gas utilities ( $\$ 24$ million), other business services ( $\$ 22$ million), construction ( $\$ 20$ million), and management and consulting ( $\$ 14$ million). These sectors combined accounted for over 95 percent of total instate LANL expenditures in FY 1998.

LANL expenditures by major sectors in New Mexico for FY 1998 were: personnel including benefits ( $\$ 628$ million), services ( $\$ 130$ million), trade ( $\$ 128$ million), other sectors ( $\$ 29$ million), construction ( $\$ 20$ million), manufacturing (\$15 million) and government ( $\$ 11$ million) (Table 6). By far the largest expenditure by LANL in the state of New Mexico was labor (\$628 million), which is over 65 percent of the statewide expenditures (Table 6), or 47 percent of the total operating and capital budget for FY 1998. Salaries and wages (without benefit costs) accounted for almost 53 percent of the total instate expenditures. In FY 1998, 13 percent of LANL expenditures went for services, 13 percent to trade, 3 percent to other sectors and utilities, 2 percent for construction, 2 percent for manufacturing, and 1 percent went to government (Figure 4).

\section{Employment}

LANL is managed and operated by the University of California, with approximately 8,931 full-time employees statewide in FY 1998. Johnson Controls had 1,381 full-time employees in FY 1998, and Protection Technology had 453 employees (Table 7). The total number of jobs (all types of personnel) statewide paid by the federal government or by contracts directly associated with LANL averaged 10,765 for FY 1998. 
Table 5. LANL Expenditures (in dollars) in New Mexico by Sector and Operating Budget, Contractors, FY 1998.

\begin{tabular}{|c|c|c|c|c|}
\hline Sector & $\begin{array}{l}\text { University of } \\
\text { California }^{\text {(o) }}\end{array}$ & $\begin{array}{l}\text { Johnson Controls, } \\
\text { Inc. }\end{array}$ & $\begin{array}{c}\text { Protection } \\
\text { Technology Los } \\
\text { Alamos } \\
\end{array}$ & Total \\
\hline \multicolumn{5}{|l|}{ 1. Livestock \& Livestock Products } \\
\hline 2. Other Agricultural Products & 80,000 & & & 80,000 \\
\hline \multicolumn{5}{|l|}{ 3. Forestry \& Fishery Products } \\
\hline 4. Agriculture, Forestry \& Fishery Services & 6,843 & & & 6,843 \\
\hline 5. Mining, Crude Petroleum \& Natural Gas & 664,409 & & & 664,409 \\
\hline 6. Construction & $20,333,745$ & & & $20,333,745$ \\
\hline 7. Ordnance \& Chemical Manufacturing & 339,500 & & & 339,500 \\
\hline 8. Food \& Kindred Products Manufacturing & 169,442 & & & 169,442 \\
\hline 9. Textiles Products \& Apparel Manufacturing & 49,868 & & & 49,868 \\
\hline 10. Lumber \& Wood Products Manufacturing & 567,967 & & & 567,967 \\
\hline 11. Paper \& Publishing Manufacturing & 91,248 & & & 91,248 \\
\hline 12. Petroleum Refining \& Products Manufacturing & 310,206 & & & 310,206 \\
\hline 13. Glass, Stone \& Clay Products Manufacturing & 54,747 & & & 54,747 \\
\hline 14. Primary \& Fabricated Metals Manufacturing & $8,122,518$ & & & $8,122,518$ \\
\hline 15. Computer, Office \& Service Equipment Manufacturing & $2,950,340$ & & & $2,950,340$ \\
\hline 16. Electrical Equipment Manufacturing & $2,541,132$ & & & $2,541,132$ \\
\hline 17. Scientific Instruments Manufacturing & 96,106 & & & 96,106 \\
\hline 18. All Other Manufacturing & 119,568 & & & 119,568 \\
\hline 19. Motor Freight Transportation \& Warehousing & 815 & & & 815 \\
\hline 20. All Other Transportation & 65,860 & & & 65,860 \\
\hline 21. Communication & $1,911,885$ & 810,692 & & $2,722,577$ \\
\hline 22. Electric \& Gas Utilities & $21,233,460$ & $2,802,953$ & & $24,036,413$ \\
\hline 23. Water \& Other Utilities & 9,525 & 19,759 & & 29,284 \\
\hline 24. Wholesale Trade & $59,232,520$ & & & $59,232,520$ \\
\hline 25. Retail Trade & $68,813,746$ & & & $68,813,746$ \\
\hline 26. Finance, Insurance \& Real Estate & $1,374,736$ & 439,951 & & $1,814,687$ \\
\hline 27. Hotel Restaurant \& Other Personal Services & 800,797 & 80,545 & & 881,342 \\
\hline 28. Dlata Processing \& Computer Services & $33,714,951$ & 239,318 & & $33,954,269$ \\
\hline 29. Management \& Consulting Services & $14,471,482$ & & & $14,471,482$ \\
\hline 30. Engineering, Architecture \& Surveying Services & $48,732,854$ & & & $48,732,854$ \\
\hline 31. Other Business Services & $21,572,966$ & 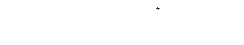 & & $21,572,966$ \\
\hline 32. A.utomobile \& Other Repair Services & $1,414,145$ & $2,248,112$ & & $3,662,257$ \\
\hline 33. Amusement, Recreation \& Video Services & 312,252 & & & 312,252 \\
\hline 34. Health, Education \& Social Services & $4,757,588$ & $1,836,142$ & & $6,593,730$ \\
\hline 35. Government Services & $8,559,837$ & & & $8,559,837$ \\
\hline 36. Local Government & 387,159 & 336,003 & & 723,162 \\
\hline 37. State Government & 903,371 & 464,004 & & $1,367,375$ \\
\hline \multicolumn{5}{|l|}{ 38. Los Alamos National Laboratory (c) } \\
\hline 39. Households & $542,695,238$ & $63,467,504$ & $22,042,451$ & $628,205,193$ \\
\hline Total New Mexico Expenditures & $867,462,826$ & $72,744,983$ & $22,042,451$ & $962,250,260$ \\
\hline Total Operating and Capital Budget & $1,206,486,093$ & $90,353,696$ & $30,609,219$ & $1,327,449,008$ \\
\hline Number of Employees & 8,931 & 1,381 & 453 & 10,765 \\
\hline \multicolumn{5}{|c|}{ a. The LANL Total Operating and Capital Budget has been adjusted to account for contracts to Johnson Controls, Inc., Protection } \\
\hline $\begin{array}{l}\text { Technology - Los Alamos and other NM DOE management \& } \\
\text { b. Expenditures by PT-LA with the exception salaries and wages } 0\end{array}$ & ting contracts. & 10 & & \\
\hline
\end{tabular}


Table 6. LANL Expenditures in New Mexico by Major Sector, FY 1998.

\section{Sector}

thousands of dollars

Percent

1. Personnel
A. Salaries \& Wages
B. Benefits
Total

508,969

52.9

119,236

12.4

628,205

65.3

II Construction

20,334

2.1

II Manufacturing

15,413

1.6

IV Trade

128,046

13.3

V. Services

130,181

13.3

VI. Government
A. Local Government
B. State Government
C. Government Services Total

723

0.1

1,367

0.1

8,560

0.9

10,650

1.1

VII. Other Sectors
A. Agriculture
B. Mining
C. T.C.U.(a)
D. F.I.R.E.(b)
Total

664

0.0

26,855

0.1

1,815

2.8

29,421

0.2

3.1

*Totals may not add due to rounding

a. Transportation, Communication and Utilities

b. Finance, Insurance and Real Estate

\section{Measuring LANL's Economic Impact on New Mexico}

The analysis of LANL's economic impact on New Mexico employed an economic model that incorporates buying and selling linkages among regional industries. This analysis measures the impact generated by LANL, the DOE/AL contractor expending money in the state. As previously stated, the term LANL is used to describe all these entities.
Several useful products of the I/O modeling technique are multipliers. Three multipliers - the first related to general economic activity, the second to income, and the third to employmentprovide the information needed to estimate LANL's impact. The activity multiplier identifies the extent to which an activity such as LANL relies directly and indirectly on the state's economy to provide the materials, services, and labor that it requires to conduct activities, and the extent to which respending by businesses and industries occurs in the state. Income and 


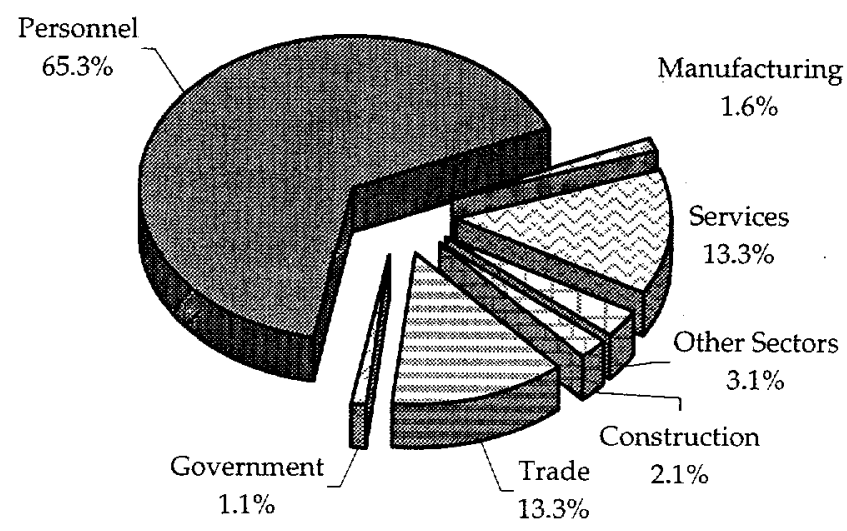

Figure 4. LANL Expenditures in New Mexico by Major Sector, FY 1998.

employment multipliers make it possible to identify not only the direct impacts of an activity on income and jobs, but also the indirect (business) and induced (households) effects.

\section{Economic Impact of LANL}

The flow diagram (Figure 5) charts the movement of monies spent by LANL. Expenditures for salaries and purchases go to households, statewide businesses, and other regions (outside the state of New Mexico). This injection of money affects economic activity directly, that is, the effect equals the amount allocated to LANL (\$1.3 billion).

Households and businesses affected by LANL respend much of the money they receive in the state, thus creating indirect (business) and induced (household) effects. In turn, businesses buy from other local firms and pay salaries to their employees, starting another round of spending. Every movement of money around the circle causes additional indirect (and induced) effects. However, some funds leak outside the region (state) when purchases are made elsewhere and are not available for further local spending. Thus, the indirect effects become smaller and smaller as continued respending occurs.

Initial spending by LANL generates substantial first-round impacts on households (net) and businesses, $\$ 575$ and $\$ 323$ million, respectively for FY 1998 (Figure 5). This initial spending will give government $\$ 11$ million in new revenues (mainly state and local government taxes, fees, and services); however, a large portion of the initial spending ( $\$ 365$ million, plus $\$ 53$ million in transfer payments and some fringe benefits costs) flows out of state through leakages.

\begin{tabular}{|c|c|c|c|}
\hline \multirow{2}{*}{$\begin{array}{r}\text { Table } 7 . \\
\text { Entity } \\
\end{array}$} & \multicolumn{3}{|c|}{$\begin{array}{l}\text { LANL Funding, Instate } \\
\text { Expenditures, and } \\
\text { Employment in New Mexico, } \\
\text { FY } 1998 .\end{array}$} \\
\hline & $\begin{array}{c}\text { New Mexico } \\
\text { Funding }\end{array}$ & $\begin{array}{c}\text { Instate } \\
\text { Expenditures }\end{array}$ & $\begin{array}{l}\text { New Mexico } \\
\text { Employment }\end{array}$ \\
\hline \multirow[b]{2}{*}{$\begin{array}{l}\text { University of } \\
\text { California } \\
\text { (LANL) }\end{array}$} & \multicolumn{2}{|c|}{-- millions of dollars .. } & jobs \\
\hline & $1,206.5$ & 867.5 & 8,931 \\
\hline $\begin{array}{l}\text { Johnson Cor } \\
\text { (LANL) }\end{array}$ & 90.4 & 72.7 & 1,381 \\
\hline PT.LA & 30.6 & 22.0 & 453 \\
\hline Total & $1,327.4$ & 962.2 & 10,765 \\
\hline
\end{tabular}

Respending by instate businesses and purchases by households and state and local governments eventually bring the total private business impact to $\$ 1.9$ billion. Also, respending activity will continue to add to personal income and government revenues so that the total personal income effect will increase to over $\$ 1.4$ billion, and state and local government tax revenues and government fees will expand to almost $\$ 213$ million as a result of direct, indirect, and induced impacts.

\section{Overall Impact}

No official figure exists for total economic activity in the state; however, for this study, a 1998 estimate of $\$ 96.5$ bilion is used (Table 8). While LANL is an important economic factor in North-Central New Mexico, the economic impacts are important but less significant when measured on a statewide basis. LANL directly added more 


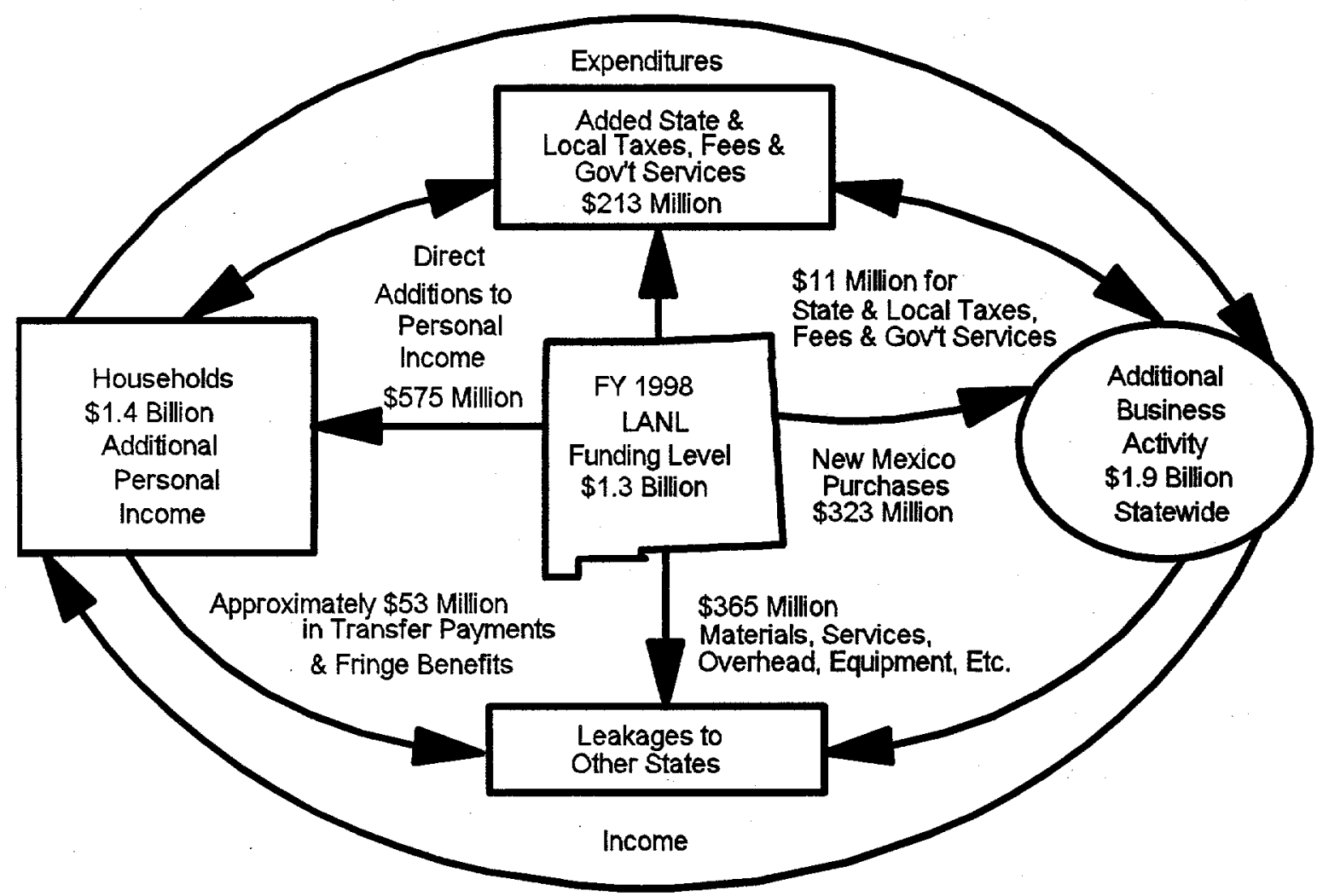

Total Statewide Economic Impact - \$4.9 Billion

Figure 5. LANL Economic Impact on the State of New Mexico, FY 1998.

than $\$ 1.3$ billion to the total state economy in FY 1998. The estimated indirect (and induced) impact of more than $\$ 3.5$ billion brings the total impact to $\$ 4.9$ billion, about 5 percent of the estimated $\$ 96.5$ billion statewide total activity in 1998 .

The estimated $\$ 4.9$ billion total economic impact in New Mexico from the initial infusion of $\$ 1.3$ billion is derived from $1 / O$ modeling techniques employed in the study. The modeling process produces estimated impacts from which multipliers can be determined. The economic activity multipliers are used to measure the volume of activity generated among various sectors of a region as a result of a $\$ 1$ exogenous change in a sector.

For example, the economic activity multiplier for LANL for FY 1998 was 3.66. This indicates that for every $\$ 1$ spent by LANL or its major on-site contractors, another $\$ 2.66$ was generated, for a total impact of $\$ 3.66$ in FY 1998 . Table 8 gives the direct, indirect, induced, and total economic activity impact of LANL on the state.
Appendix Table 12 gives LANL indirect economic impacts on private and public sectors for FY 1998. The retail trade sector received the greatest volume of indirect economic impacts, about 17 percent of the total estimated public and private sector volume of indirect impacts. Other sectors with large indirect impacts were FIRE (14 percent), hotel, restaurant and other personal services, wholesale trade, other business services, electric and gas utilities, and health, education and social services (all about 5 percent each).

\section{Impact on Income}

Personal income is money that goes to individuals to be respent for items such as groceries, automobiles and gasoline, mortgage payments, medical, clothing and new shoes, taxes, and savings. Most personal income consists of wages and salaries, although payments received as interest, rent, dividends, and Social Security benefits (payments to individuals) also count as personal income. 
Table 8. LANL State Influence on New Mexico's Economy, FY 1998.

\begin{tabular}{|c|c|c|c|}
\hline Economic Measure & LANL & Total State & $\begin{array}{c}\text { LANL as } \% \text { of } \\
\text { State }\end{array}$ \\
\hline & \multicolumn{2}{|c|}{----billions of dollars---- } & \\
\hline \multicolumn{4}{|l|}{ Economic Activity } \\
\hline Director Expenditures & 1.33 & & \\
\hline Indirect and Induced (a) & $\underline{3.54}$ & & \\
\hline Total Economic Activity & 4.86 & 96.5 & 5.0 \\
\hline Economic Activity Multiplier & 3.66 & & \\
\hline \multicolumn{4}{|l|}{ Personal Income } \\
\hline Gross Labor Costs & 0.63 & & \\
\hline Net Wage and Salaries & 0.57 & & \\
\hline Indirect and Induced (a) & $\underline{0.83}$ & & \\
\hline Total Personal Income & 1.40 & $34.8(a)$ & 4.0 \\
\hline \multirow[t]{2}{*}{ Personal Income Multiplier } & 2.44 & & \\
\hline & \multicolumn{2}{|c|}{. - number of employees- - } & \\
\hline \multicolumn{4}{|l|}{ Ermployment } \\
\hline Direct & 10,765 & & \\
\hline Indirect and Induced (a) & $\underline{25,629}$ & & \\
\hline Total Employment & 36,394 & 831,052 (b) & 4.4 \\
\hline Enployment Multiplier & 3.38 & & \\
\hline
\end{tabular}

a. BEA May 1999

b. New Mexico Department of Labor, Table C, March 1999.

Some of the fringe benefits and wages paid to employees are not counted in the current income stream (i.e., Social Security payments by employers and employees). In FY 1998, labor payments of $\$ 628$ million resulted in an estimated $\$ 575$ million in net additional personal income.

Income multipliers measure the indirect and induced effects of new income generated from payment to labor by LANL. The income multiplier was 2.44 for FY 1998 (Table 8).
Application of the income multiplier of 2.44 to the direct net personal income figure of $\$ 575$ million yields a total impact of slightly over $\$ 1.4$ billion for income resulting from LANL activity. This multiplier indicates that for every $\$ 1$ of personal income from LANL for labor, another $\$ 1.44$ is generated through indirect and induced effects. 
In FY 1998, total personal income in New Mexico was estimated at $\$ 34.8$ billion (Table 8). LANL activities in New Mexico accounted for about 4 percent of total personal income in 1998.

\section{Impact on Employment}

Beside this dollars-and-cents impact, LANL affects statewide employment. In addition to the average of 10,765 mainly full-time jobs created by LANL in FY 1998, other jobs are supported by needs for goods and services and respending by individuals and businesses. Firms filling those needs have their own employees, and in turn, spend money with other firms who must also hire people. Additionally, each individual employee demands goods and services and, therefore, supports other jobs such as waitresses, mechanics, clerks, lawyers, and nurses.

Employment multipliers measure the number of indirect and induced jobs supported, on the average, by LANL. The employment multiplier for LANL was estimated to be 3.38 in FY 1998 (Table 8). This indicates that for every 100 jobs created by LANL, another 238 jobs were supported in FY 1998. Considering the multiplier effect, 10,765 jobs translates into a total impact of 36,394 jobs created or supported by LANL or over 4 percent of total employment in the state in FY 1998 (see Table 8).

Table 12 in the Appendix gives LANL indirect employment impact on the private and public sectors for FY 1998. The more labor-intensive sectors received the greater indirect employment impact. The retail trade sector had the largest indirect impact, about 29 percent of the indirect impact. Other sectors with a large indirect employment impact include: hotel, restaurant, and personal services ( 11 percent); FIRE ( 9 percent); health education and social services ( 7 percent); wholesale trade ( 6 percent); and other business services ( 4 percent).

\section{CONCLUSIONS}

In summary, LANL operations in New Mexico have a significant and positive influence on the economy of New Mexico. The funding for LANL in New Mexico, slightly over $\$ 1.3$ billion in FY 1998 , supported a total economic impact of $\$ 4.9$ billion or about 5 percent of total economic activity in the state.

Total personal income impacts were over $\$ 1.4$ billion in FY 1998 or about 4 percent of personal income derived in New Mexico. The employment multiplier was 3.38 for the state, meaning that the 10,765 average employment level in FY 1998 supported a total impact of 36,394 . In effect, about one of every 23 jobs in the state was created or supported by LANL. Approximately 76 percent of the jobs created indirectly by LANL in the region occurred in the trade, FIRE, and services sectors. 


\section{REFERENCES}

Adcock, Larry. "Effective Tax Rates for New Mexico, 1986." Los Alamos National Laboratory. Unpublished manuscript, Los Alamos, New Mexico.

Adcock, L.D., T.M. Cohen, R.R. Lansford, D.J. Post, and S.L. Runyon, 1992. "The Social and Economic Impacts of the Department of Energy on the State of New Mexico, FY 1991." U.S. DOE Albuquerque, Albuquerque Operations Office, Albuquerque, New Mexico.

Adcock, L.D., and R.R. Lansford, 1991. "The Social and Economic Impacts of the Department of Energy on the State of New Mexico, FY 1990." U.S. DOE Albuquerque, Albuquerque Operations Office, Albuquerque, New Mexico.

Adcock, L.D., and R.R. Lansford, 1990. "The Social and Economic Impacts of the Department of Energy on the State of New Mexico, FY 1989." U.S. DOE Albuquerque, Albuquerque Operations Office, Albuquerque, New Mexico.

Adcock. L.D., R.R. Lansford, and A. Turpin, 1989. "The Social and Economic Impact of the Department of Energy on the State of New Mexico, FY 1988." U.S. DOE Albuquerque, Albuquerque Operations Office, Report No. APD-89-2, Albuquerque, NewMexico.

Adcock, Larry and Larry Waldman, "A Non-Survey Technique for Constructing a Direct Requirements Regional Input-Output Table." Proceedings 1975 Conference of the Association for University and Business Research, Virginia, edited at Arizona State University, Tempe, Arizona.

Carruthers, Garrey, K. Mitchell, and Thomas Williams, 1972. "An Inter-industry Model of the Economy of North-Central New Mexico," Agricultural Experiment Station Research Report 237, New Mexico State University, Las Cruces, New Mexico.
Cohen, T.M., L.D. Adcock, and R.R. Lansford, 1992. "The Economic Impact of Los Alamos National Laboratory and Sandia National Laboratories on the State of New Mexico FY 1990." Agricultural Experiment Station, Technical Report 7, New Mexico State University, Las Cruces, New Mexico.

Lansford, R.R., L.D. Adcock, S. Ben-David, L.M. Gentry, and J. Temple, 1999. "The Social and Economic Impacts of the Department of Energy on the State of New Mexico, FY 1998." U.S. DOE Albuquerque, Albuquerque Operations Office, Albuquerque, New Mexico.

Lansford, R.R., L.D. Adcock, S. Ben-David L. M. Gentry, T.G. Nielsen, J. Schultz, and J. Temple, 1997. "The Social and Economic Impacts of the Department of Energy on the State of New Mexico, FY 1996." U.S. DOE Albuquerque, Albuquerque Operations Office, Albuquerque, New Mexico.

Lansford, R.R., L.D. Adcock, S. Ben-David L. M. Gentry, T.G. Nielsen, J. Schultz, and J. Temple, 1997. "The Economic Impact of Los Alamos National Laboratory on North-Central New Mexico, FY 1996." US DOE Albuquerque, Albuquerque Operations Office, Albuquerque, New Mexico.

Lansford, R.R., L.D. Adcock, L.M. Gentry and S. Ben-David, 1997. "The Economic Impact of the Department of Energy on the State of New Mexico, FY 1996." US DOE Albuquerque, Albuquerque Operations Office, Albuquerque, New Mexico.

Lansford, R.R., L.D. Adcock, L.M. Gentry and S. Ben-David, 1997. "The Economic Impact of Los Alamos National Laboratory on NorthCentral New Mexico, FY 1996." US DOE Albuquerque, Albuquerque Operations Office, Albuquerque, NM.

Lansford, R.R., L.D. Adcock, L.M. Gentry and S. Ben-David, 1997. "The Economic Impact of Los Alamos National Laboratory on NorthCentral New Mexico, FY 1996." US DOE Albuquerque, Albuquerque Operations Office, Albuquerque, New Mexico. 
Lansford, R.R., L.D. Adcock, L.M. Gentry and S. Ben-David, 1996. "The Economic Impact of the Department of Energy on the State of New Mexico, FY 1995." US DOE Albuquerque, Albuquerque Operations Office, Albuquerque, New Mexico.

Lansford, R.R., L.D. Adcock, L.M. Gentry and S. Ben-David, 1996. "The Economic Impact of Los Alamos National Laboratory on NorthCentral New Mexico, FY 1995." US DOE Albuquerque, Albuquerque Operations Office, Albuquerque, New Mexico

Lansford, R.R., L.D. Adcock, L.M. Gentry and S. Ben-David, 1995. "The Economic Impact of the Department of Energy on the State of New Mexico, FY 1994." US DOE Albuquerque, Albuquerque Operations Office, Albuquerque, New Mexico.

Lansford, R.R., L.D. Adcock, L.M. Gentry and S. Ben-David, 1995. "The Economic Impact of Los Alamos National Laboratory on NorthCentral New Mexico, FY 1994." US DOE Albuquerque, Albuquerque Operations Office, Albuquerque, New Mexico.

Lansford, R.R., L.D. Adcock, L.M. Gentry and S. Ben-David, 1994. "The Economic Impact of the Department of Energy on the State of New Mexico, FY 1993." US DOE Albuquerque, Albuquerque Operations Office, Albuquerque, New Mexico.

Lansford, R.R., L.D. Adcock, S. Ben-David, and S.L, Runyon, 1993. "The Economic Impact of the Department of Energy on the State of New Mexico FY 1992." U.S. DOE Albuquerque, Albuquerque Operations Office, Albuquerque, New Mexico..

Lansford, R.R., L.D. Adcock, L.M. Gentry and S. Ben-David, 1993. "The Economic Impact of Los Alamos National Laboratory on NorthCentral New Mexico, FY 1994." US DOE Albuquerque, Albuquerque Operations Office, Albuquerque, New Mexico.

Lansford, R.R., J.A. Diemer, E.M. Jaramillo, A Turpin, D. Williams, V. Devers, and L. Adcock, 1988. "The Social and Economic Impact of the Department of Energy on the State of New Mexico, FY 1987," Special Report 79, Agricultural Experiment Station,
New Mexico State University, Las Cruces, New Mexico.

Morris, Donald, Larry Adcock, Steven Booth, 1986. "Los Alamos National Laboratory: A Regional Economic Impact Study," Los Alamos National Laboratory Report LA-UR-3206, Los Alamos, New Mexico.

New Mexico Department of Labor, April 1989. "New Mexico Labor Market, Annual Planning Report," Bureau of Economic Research and Analysis, University of New Mexico, Albuquerque, New Mexico.

New Mexico Department of Labor, January 1991. "Covered Employment and Wages," Quarterly Report, Quarter 1989 and First Quarter 1990; Economic Research and Analysis Bureau, Albuquerque, New Mexico.

New Mexico Department of Labor, April 1993. "Table A," Economic Research and Analysis Bureau, Albuquerque, New Mexico.

New Mexico Department of Labor. "Report of Employment, Wages, and Contributions (Es-202)," Economic Research and Analysis Bureau, Albuquerque, New Mexico; unpublished information.

Runyon, Shannon L, 1993. Effective Tax Rates for New Mexico by Economic Sector, M.S. thesis, New Mexico State University, Las Cruces, New Mexico.

Sunwest Financial Services, Inc., 1992, "New Mexico Progress, Economic Review of 1991," in draft; Sunwest Financial Services, Inc. P.O. Box 25500, Albuquerque, New Mexico.

Turpin, Annette, Larry Adcock, and Donna Williams, 1987. "The Economic Impact of the United States Department of Energy on the State of New Mexico Fiscal Years 1985 and 1986," Los Alamos National Laboratory Miscellaneous Report, Los Alamos, New Mexico.

U.S. Department of Commerce, April 1, 1997. "New Mexico Population by Race and Ethnicity 1997," Bureau of the Census, PL-94-171, Washington, D.C. 
U.S. Department of Agriculture, 1997.

"Agricultural Statistics 1996," U.S. Government Printing Office, Washington D.C.

U.S. Department of Agriculture, 1998, "New Mexico Agricultural Statistics, 1997," New Mexico Agricultural Statistics Service, Las Cruces, New Mexico.

U.S. Department of Agriculture, 1997, "New Mexico Agricultural Statistics, 1996," New Mexico Agricultural Statistics Service, Las Cruces, New Mexico.

U.S. Department of Commerce, July 1991, "Benchmark Input-Output Accounts for the U.S. Economy, 1987," Survey of Current Business, Washington, D.C.

U.S. Department of Commerce, 1986. "County Business Patterns of 1984, New Mexico," B u rea of $t$ he Census, CBP-84-33. Washington, D.C. 


\begin{tabular}{|c|c|}
\hline Sector & $\begin{array}{c}\text { Direct } \\
\text { Coefficients }\end{array}$ \\
\hline 1. Livestock \& Livestock Products & 0.000000 \\
\hline 2. Other Agricultural Products & 0.000000 \\
\hline 3. Forestry \& Fishery Products & 0.000000 \\
\hline 4. Agriculture, Forestry \& Fishery Services & 0.000005 \\
\hline 5. Mining, Crude Petroleum \& Natural Gas & 0.000009 \\
\hline 6. Construction & 0.007710 \\
\hline 7. Ordnance \& Chemical Manufacturing & 0.000206 \\
\hline 8. Food \& Kindred Products Manufacturing & 0.000000 \\
\hline 9. Textiles Products \& Apparel Manufacturing & 0.000024 \\
\hline 10. Lumber \& Wood Products Manufacturing & 0.000016 \\
\hline 11. Paper \& Publishing Manufacturing & 0.000015 \\
\hline 12. Petroleum Refining \& Products Manufacturing & 0.000000 \\
\hline 13. Glass, Stone \& Clay Products Manufacturing & 0.000027 \\
\hline 14. Primary \& Fabricated Metals Manufacturing & 0.002522 \\
\hline 15. Computer, Office \& Service Equipment Manufacturing & 0.001381 \\
\hline 16. Electrical Equipment Manufacturing & 0.001715 \\
\hline 17. Scientific Instruments Manufacturing & 0.000000 \\
\hline 18. All Other Manufacturing & 0.000000 \\
\hline 19. Motor Freight Transportation \& Warehousing & 0.000001 \\
\hline 20. All Other Transportation & 0.000018 \\
\hline 21. Communication & 0.000641 \\
\hline 22. Electric \& Gas Utilities & 0.002124 \\
\hline 23. Water \& Other Utilities & 0.000015 \\
\hline 24. Wholesale Trade & 0.016990 \\
\hline 25. Retail Trade & 0.030832 \\
\hline 26. Finance, Insurance \& Real Estate & 0.001367 \\
\hline 27. Hotel Restaurant \& Other Personal Services & 0.000614 \\
\hline 28. Data Processing \& Computer Services & 0.017487 \\
\hline 29. Management \& Consulting Services & 0.009167 \\
\hline 30. Engineering, Architecture \& Surveying Services & 0.031839 \\
\hline 31. Other Business Services & 0.011023 \\
\hline 32. Automobile \& Other Repair Services & 0.002197 \\
\hline 33. Amusement, Recreation \& Video Services & 0.000049 \\
\hline 34. Health, Education \& Social Services & 0.003277 \\
\hline 35. Government Services & 0.006135 \\
\hline 36. Local Government & 0.000253 \\
\hline 37. State Government & 0.000350 \\
\hline 38. Los Alamos National Laboratory & 0.000000 \\
\hline 39. Households & 0.433973 \\
\hline Total New Mexico Expenditures & 0.581978 \\
\hline Totäl Operating and Capital Budget & 1.000000 \\
\hline
\end{tabular}


Sector

Direct

1. Livestock \& Livestock Products

Coefficients

2. Other Agricultural Products

0.000000

3. Forestry \& Fishery Products

0.000000

4 Agriculture, Forestry \& Fishery Services

0.000060

5. Mining, Crude Petroleum \& Natural Gas

0.000000

6. Construction

0.000005

7. Ordnance \& Chemical Manufacturing

0.000501

8. Food \& Kindred Products Manufacturing

0.015318

9. Textiles Products \& Apparel Manufacturing

0.000256

10. Lumber \& Wood Products Manufacturing

0.000128

11. Paper \& Publishing Manufacturing

0.000038

12. Petroleum Refining \& Products Manufacturing

0.000428

13. Glass, Stone \& Clay Products Manufacturing

0.000069

14. Primary \& Fabricated Metals Manufacturing

0.000234

15. Computer, Office \& Service Equipment Manufacturing

0.000041

16. Electrical Equipment Manufacturing

0.006119

17. Scientific Instruments Manufacturing

0.002223

18. Alt Other Manufacturing

0.001914

19. Motor Freight Transportation \& Warehousing

0.000072

20. All Other Transportation

0.000090

21. Communication

0.000001

22. Electric \& Gas Utilities

0.000050

23. Water \& Other Utilities

0.002051

24. Wholesale Trade

0.018107

25. Retail Trade

0.000022

26. Finance, Insurance \& Real Estate

0.044621

27. Hotel Restaurant \& Other Personal Services

0.051839

28. Data Processing \& Computer Services

0.001367

29. Management \& Consulting Services

0.000664

30. Engineering, Architecture \& Surveying Services

0.025579

31. Other Business Services

0.010902

0.036712

32. Automobile \& Other Repair Services

0.016251

33. Amusement, Recreation \& Video Services

0.002759

34. Health, Education \& Social Services

0.000235

35. Government Services

0.004967

36. Local Government

0.000545

37. State Government

0.001030

38. Los Alamos National Laboratory

0.000000

39. Households

0.473242

Total New Mexico Expenditures

0.724887

Total Operating and Capital Budget

1.000000 
Table 11. Indirect Volume and Employment Impacts by Sector, LANL, NorthCentral New Mexico, FY 1998

\begin{tabular}{|c|c|c|c|c|}
\hline \multirow[b]{2}{*}{ Sector } & \multicolumn{2}{|c|}{ Volume } & \multicolumn{2}{|c|}{ Employment } \\
\hline & $(\$ 000)$ & $\%$ & Jobs & $\%$ \\
\hline 1. Livestock and Livestock Products & 4111. & 0.3 & 11. & 0.1 \\
\hline 2. Other Agricultural Products & 7177. & 0.5 & 40. & 0.2 \\
\hline 3. Forestry and Fishery Products & 385. & 0.0 . & 2. & 0.0 \\
\hline 4. Agricultural, Forestry, and Fishery Services & 1725. & 0.1 & 36. & 0.2 \\
\hline 5. Mining, Crude Petroleum, and Natural Gas & 2866. & 0.2 & 10. & 0.1 \\
\hline 6. Construction & 52445. & 3.8 & 591. & 3.3 \\
\hline 7. Ordnance and Chemical Manufacturing & 520. & 0.0 & 3. & 0.0 \\
\hline 8. Food and Kindred Products Manufacturing & 25969. & 1.9 & 131. & 0.7 \\
\hline 9. Textile Products and Apparel Manufacturing & 5665. & 0.4 & 61. & 0.3 \\
\hline 10. Lumber and Wood Products Manufacturing & 1501. & 0.1 & 16. & 0.1 \\
\hline 11. Paper and Publishing Manufacturing & 6130. & 0.4 & 70. & 0.4 \\
\hline 12. Petroleum Refining and Products Manufacturing & 18986. & 1.4 & 13. & 0.1 \\
\hline 13. Glass, Stone and Clay Products Manufacturing & 2014. & 0.1 & 20. & 0.1 \\
\hline 14. Primary and Fabricated Metals Manufacturing & 5180. & 0.4 & 45. & 0.3 \\
\hline 15. Computer, Office and Service Equipment Mfg. & 12592. & 0.9 & 74. & 0.4 \\
\hline 16. Electrical Equipment Manufacturing & 3737. & 0.3 & 19. & 0.1 \\
\hline 17. Scientific Instruments Manufacturing & 809. & 0.1 & 5. & 0.0 \\
\hline 18. All Other Manufacturing & 2669. & 0.2 & 28. & 0.2 \\
\hline 19. Motor Freight Transportation and Warehousing & 5113. & 0.4 & 70. & 0.4 \\
\hline 20. All Other Transportation & 10013. & 0.7 & 121. & 0.7 \\
\hline 21. Communication & 30403. & 2.2 & 259. & 1.4 \\
\hline 22. Electric and Gas Utilities & 50737. & 3.6 & 72. & 0.4 \\
\hline 23. Water and Other Utilities & 8275 . & 0.6 & 38. & 0.2 \\
\hline 24. Wholesale Trade & 59483. & 4.3 & 688. & 3.8 \\
\hline 25. Retail Trade & 275831. & 19.8 & 5603. & 31.2 \\
\hline 26. Finance, Insurance and Real Estate & 224557 & 16.1 & 1735. & 9.7 \\
\hline 27. Hotel Restaurant and Other Personal Services & 77813. & 5.6 & 2216. & 12.4 \\
\hline 28. Data Processing and Computer Services & 35966. & 2.6 & 322. & 1.8 \\
\hline 29. Management and Consulting Services & 26984. & 1.9 & 167. & 0.9 \\
\hline 30. Engineering, Architecture and Surveying Services & 51985. & 3.7 & 428. & 2.4 \\
\hline 31. Other Business Services & 70242. & 5.0 & 691. & 3.9 \\
\hline 32. Automobile and Other Repair Services & 50372. & 3.6 & 466. & 2.6 \\
\hline 33. Amusement, Recreation and Video Services & 27660. & 2.0 & 577. & 3.2 \\
\hline 34. Health, Education and Social Services & 74836. & 5.4 & 1385. & 7.7 \\
\hline TOTAL Private Sector & 1234748 . & 88.5 & 16011 & 89.3 \\
\hline 35. Government Services & 24996. & 1.8 & 270. & 1.5 \\
\hline 36. Local Government & 49973. & 3.6 & 658. & 3.7 \\
\hline 37. State Government & 85733. & 6.1 & 992. & 5.5 \\
\hline TOTAL Public Sector & 160701. & 11.5 & 1920. & 10.7 \\
\hline TOTAL Private and Public Sectors & 1395450. & 100.0 & 17931 & 100.0 \\
\hline
\end{tabular}

Totals may not add due to rounding 
Table 12. Indirect Volume and Employment Impacts by Sector, LANL, State Of New Mexico, FY 1998

\begin{tabular}{|c|c|c|c|c|}
\hline \multirow[b]{2}{*}{ Sector } & \multicolumn{2}{|c|}{ Volume } & \multicolumn{2}{|c|}{ Employment } \\
\hline & $(\$ 000)$ & $\%$ & Jobs & $\%$ \\
\hline 1. Livestock and Livestock Products & 9048. & 0.4 & 24. & 0.1 \\
\hline 2. Other Agricultural Products & 10536. & 0.5 & 59. & 0.2 \\
\hline 3. Forestry and Fishery Products & 500. & 0.0 & 2. & 0.0 \\
\hline 4. Agricultural, Forestry, and Fishery Services & 2033. & 0.1 & 42. & 0.2 \\
\hline 5. Mining, Crude Petroleum, and Natural Gas & 55222 & 2.6 & 188. & 0.7 \\
\hline 6. Construction & 78892 & 3.7 & 890. & 3.5 \\
\hline 7. Ordnance and Chemical Manufacturing & 3386. & 0.2 & 20. & 0.1 \\
\hline 8. Food and Kindred Products Manufacturing & 39059. & 1.8 & 197. & 0.8 \\
\hline 9. Textile Products and Apparel Manufacturing & 7187. & 0.3 & 77. & 0.3 \\
\hline 10. Lumber and Wood Products Manufacturing & 3416. & 0.2 & 36. & 0.1 \\
\hline 11. Paper and Publishing Manufacturing & 10742. & 0.5 & 122. & 0.5 \\
\hline 12. Petroleum Refining and Products Manufacturing & 41482 & 1.9 & 28. & 0.1 \\
\hline 13. Glass, Stone and Clay Products Manufacturing & 5529. & 0.3 & 54. & 0.2 \\
\hline 14. Primary and Fabricated Metals Manufacturing & 15699. & 0.7 & 137. & 0.5 \\
\hline 15. Computer, Office and Service Equipment Mfg. & 44897. & 2.1 & 264. & 1.0 \\
\hline 16. Electrical Equipment Manufacturing & 21172. & 1.0 & 108. & 0.4 \\
\hline 17. Scientific Instruments Manufacturing & 1977. & 0.1 & 12. & 0.0 \\
\hline 18. All Other Manufacturing & 7140. & 0.3 & 76. & 0.3 \\
\hline 19. Motor Freight Transportation and Warehousing & 16298. & 0.8 & 222. & 0.9 \\
\hline 20. All Other Transportation & 24797. & 1.2 & 299. & 1.2 \\
\hline 21. Communication & 49631. & 2.3 & 423. & 1.7 \\
\hline 22. Electric and Gas Utilities & 104682. & 4.9 & 149. & 0.6 \\
\hline 23. Water and Other Utilities & 11212. & 0.5 & 52. & 0.2 \\
\hline 24. Wholesale Trade & 128043. & 6.0 & 1480. & 5.8 \\
\hline 25. Retail Trade & 367322 . & 17.2 & 7462. & 29.1 \\
\hline 26. Finance, Insurance and Real Estate & 294312. & 13.8 & 2273. & 8.9 \\
\hline 27. Hotel Restaurant and Other Personal Services & 99692. & 4.7 & 2839. & 11.1 \\
\hline 28. Data Processing and Computer Services & 53689. & 2.5 & 481. & 1.9 \\
\hline 29. Management and Consulting Services & 34628. & 1.6 & 214. & 0.8 \\
\hline 30. Engineering, Architecture and Surveying Services & 62909. & 2.9 & 518. & 2.0 \\
\hline 31. Other Business Services & 108293. & 5.1 & 1065. & 4.2 \\
\hline 32. Automobile and Other Repair Services & 73982. & 3.5 & 685. & 2.7 \\
\hline 33. Amusement, Recreation and Video Services & 38822. & 1.8 & 810. & 3.2 \\
\hline 34. Health, Education and Social Services & 95978. & 4.5 & 1776. & 6.9 \\
\hline TOTAL Private Sector & 1922205. & 90.0 & 23082. & 90.1 \\
\hline 35. Government Services & 29949. & 1.4 & 323. & 1.3 \\
\hline 36. Local Government & 65418. & 3.1 & 862. & 3.4 \\
\hline 37. State Government & 117733. & 5.5 & 1362. & 5.3 \\
\hline TOTAL Public Sector & 213100 . & 10.0 & 2547. & 9.9 \\
\hline TOTAL Private and Public Sectors & 2135305. & 100.0 & 25629 & 100.0 \\
\hline
\end{tabular}

Totals may not add due to rounding 